\title{
Maternal Life Stage
}

National Cancer Institute

\section{Source}

National Cancer Institute. Maternal Life Stage. NCI Thesaurus. Code C90337.

The period of time during a female's reproductive years that she functions as a mother. 